POLIIICAL ECONOMY RESEARCH INSTIIUIE

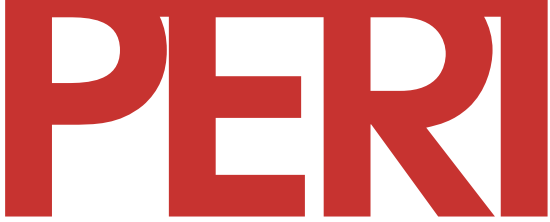

University of Massachusetts Amherst

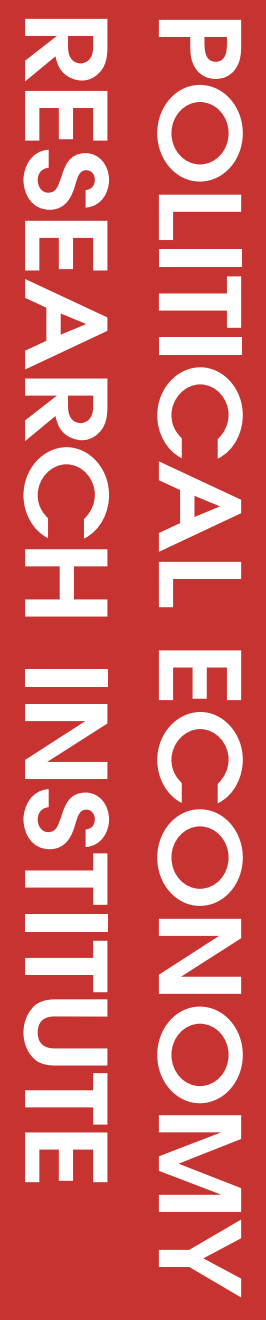

\title{
Evaluating Living Wage Laws in the United States: Good Intentions and Economic Reality in Conflict?
}

Robert Pollin

2003

10th floor Thompson Hall University of Massachusetts Amherst, MA, 01003-7510 Telephone: (413) 545-6355 Facsimile: (413) 545-2921 Email:peri@econs.umass.edu Website:

http://www.umass.edu/peri/

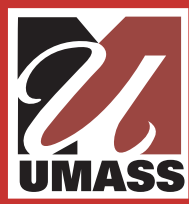




\title{
Evaluating Living Wage Laws in the United States: Good Intentions and Economic Reality in Conflict?
}

\author{
Robert Pollin \\ Professor of Economics and \\ Co-Director, Political Economy Research Institute (PERI) \\ University of Massachusetts-Amherst \\ Amherst, MA 01003 \\ pollin@econs.umass.edu
}

Draft: June 2003

\begin{abstract}
This paper first examines the question "what is a living wage" and provides a range of specific dollar amounts derived a conceptual assessment of the term. I then provide a series of cost estimates of living wage laws in various cities. Based on these cost estimates, I examine a set of alternative adjustments that covered firms could make to absorb these costs, including raising prices and productivity, redistributing the firm's income more equally, laying off employees and relocating out of the area covered by the law. I draw upon both prospective and retrospective evidence to reach an overall assessment of the benefits of living wage laws relative to their costs.
\end{abstract}

JEL CLASSIFICATION：J38

This paper builds from a series of research projects I have undertaken in collaboration with co-workers at the Political Economy Research Institute. I acknowledge with respect and appreciation the contributions of Jeanette Wicks-Lim, Stephanie Luce, and Mark Brenner. I am also grateful for the comments by three anonymous referees and Timothy Bartik, the coeditor of this journal. 
"In Economics, "other things" are so often not equal that greater proportionate stress ought to be laid on the necessity of examining each case to see whether the weights are important or not."

-- Alfred Marshall letter to Bowley, February 21, 1901, Vol 2, of Collected Correspondence p. 301

As of October 2002, living wage proposals have passed into law in about 90 municipalities in the United States since the first ordinance was approved by the Baltimore City Council in 1995. But this is not the first living wage movement in the U.S. Indeed the initial establishment of minimum wage laws in the U.S.- - first at the state level beginning with Massachusetts in 1912 then moving to the Federal level through various measures between 193336-was itself the culmination of an explicit "living wage" movement. One of the most influential works supporting the movement was a 1906 book by Monsignor John A. Ryan titled A Living Wage: Its Ethical and Economic Aspects. By the mid-1930s, President Franklin D. Roosevelt made his position on the issue clear, stating that "no business which depends for existence on paying less than living wages to its workers has any right to exist in this country."

The contemporary living wage movement spread throughout the country from its inception point in Baltimore as a response to the declining fortunes of low-wage workers and, more generally, the sharply rising trend in wage and income inequality in the U.S. economy. Thus, the real value of the national minimum wage as of 2001, at $\$ 5.15$ per hour, was 37 percent below its peak value in 1968 of $\$ 8.14$ (in constant 2001 dollars), even while average labor productivity rose in the U.S. by roughly 80 percent between $1968-2001$. This means that if the real value of the national minimum wage had risen exactly in step with the rate of productivity growth, the minimum wage as of 2001 would be $\$ 14.65$. More to the point, someone who works full-time for 52 weeks at the $\$ 5.15$ national minimum would earn $\$ 10,712$ over a year. This figure is 12.2 percent below the 2001 national poverty threshold for a family of two ( 1 adult, 1

\footnotetext{
${ }^{1}$ Glickman (1997) is a book length history of living wage movements in the United States during the $20^{\text {th }}$ century. The quote from Roosevelt is cited in Stabile (1993), p. 13, which in turn cites Barkin (1937), p. 7, as the original reference.
} 
child) and a broad range of researchers consider such official poverty thresholds themselves to be between 25 and 50 percent too low. ${ }^{2}$

Similarly, the real value of the average wage for non-supervisory workers stood in 2001 at $\$ 14.31$, which is 8.9 percent below its peak value in 1973 of $\$ 15.71$ (in constant 2001 dollars), even after the average real wage rose significantly between 1997-99 and continued rising, though more modestly, in 2000 and 2001. Moreover, these declines in the absolute values of the minimum and average wage have occurred while earnings for high-wage workers rose substantially and compensation for corporate CEOs exploded. Thus, the wage for workers at the $10^{\text {th }}$ wage decile fell from 28 to 23 percent of workers at the $90^{\text {th }}$ wage decile between $1976-$ 2001. Meanwhile, average CEO compensation rose from 38 to 449 times that of an average nonsupervisory production worker between $1970-2001 .^{3}$

Despite these trends, opponents of living wage ordinances argue that these measures will not benefit, but will actually hurt, the very low-wage workers and their families that the movement is trying to assist. In other words, according to opponents, the living wage movement is a classic case of the "law of unintended consequences" as it operates in economics-that is, well-meaning people ending up doing harm while seeking to do good, through their misapprehension as to how economic policy interventions play themselves out in actual market settings. Opponents point to three major unintended consequences of living wage ordinances:

1) They will cause a contraction of employment opportunities for low-wage workers and/or a displacement of currently employed workers by those possessing higher skills.

2) They will induce firms located in cities with living wage ordinances to relocate out of these areas, as a means of avoiding being covered by the mandates of the law; and

3) They will create significant new costs for municipal governments. This will mean that governments will have fewer resources to support their existing measures aimed at reducing poverty and promoting increased job opportunities.

\footnotetext{
${ }^{2}$ Citro and Michael (1995) is the most extensive contemporary examination of the poverty thresholds, a topic to which we return below.

${ }^{3}$ Original sources for data in this paragraph are presented in Pollin (2003).
} 
In the rest of this paper, I address these basic issues concerning living wage laws, drawing on the existing research I have produced with colleagues along with the work by others in the field.

In Section 2, I examine the initial fundamental matter of concern, posing the question, "what is a living wage" in the context of the contemporary U.S. economy. As we will see, the answer is not obvious, even at a conceptual level. But it is even more challenging to move from a conceptual consideration of the issue to establishing quantitative benchmarks that define living wages in terms of specific hourly wage rates. Drawing on earlier research, I provide a range of values for a living wage in the Los Angeles area. This set of figures reflects both different notions of the term "living wage" as well as an accounting for regional variation in the cost of living.

But establishing a set of figures for living wages does not provide information as to whether establishing a minimum wage mandate at any of the threshold figures would trigger significant negative unintended consequences. To begin to address this question, in Section 3 I provide summary figures on how much ordinances are likely to cost. I draw here on estimates my co-authors and I have derived for three different living wage ordinances—-that which has been in operation in Los Angeles since 1997, as well as measures that have been considered in both New Orleans, LA and Santa Monica, CA. The key figure in these exercises is our estimate of the full costs to covered firms of a given living wage ordinance relative to some relevant measure-either total costs of production or total sales-of the firms' total operations. As we will see, in all three cases, we find that for the average firms covered by living wage ordinances, the costs of the ordinance range between $1-2$ percent or less of the firm's total production costs or sales. But we also report on the situation for firms that experience significantly higher cost increases, such as the hotels and restaurants in the Santa Monica case, which would face cost increases on the order of 10 percent of total sales. 
In Section 4, I then consider how firms faced with cost increases of the magnitudes we estimate are likely to respond. Layoffs and relocatons are two possible adjustment paths and, of course, both would entail negative intended consequences. But these are not the only possible ways through which firms could adjust to their living wage-induced cost increases. Depending on their cost structures and production processes, firms could also absorb the increased costs through three other means: 1) raising prices; 2) raising productivity; or 3) redistributing income within the firm, either through wage compression or a fall in profit shares. The advantage for covered firms of these three other adjustment mechanisms relative to layoffs or relocations is that, within a reasonable range of small adjustments, firms could implement them more quickly and at lower cost to themselves than either layoffs or relocations.

In terms of costs to municipalities, it similarly does not follow that the higher wage costs would necessarily be passed back to government budgets dollar-for-dollar via more expensive service contracts. It would be reasonable to consider that at least some portion of the higher wage costs might be absorbed by private firms competing for municipal contracts. Again, this is most likely to be true when the costs of a living wage ordinance to private firms are relatively small.

Thus, I evaluate in Section 4 the extent to which firms are likely to pursue the various possible adjustment options they face. I consider the issue first in terms of the evidence I report on prospective costs, what I will term prospective evidence. I then consider whether the conclusions I draw based on prospective evidence are consistent with retrospective analysis of the experience with implementing living wage ordinances in four cities-Baltimore, Boston, New Haven, CT and Hartford CT. The specific retrospective evidence on which I focus is how awards for city service contracts have changed after living wage ordinances were implemented in these four cities.

The living wage ordinances in these four cities for which we have retrospective evidence, and indeed all of the living wage ordinances that have become law thus far, are designed in similar ways. They are what I term "contractors-only" ordinances because they apply only to 
firms either holding service contracts with, or receiving subsidies from, city governments. At the same time, various cities, including New Orleans and Santa Monica, have considered ordinances which apply to all businesses of a given size within a given geographic region, what I term "areawide" measures. In Section 5, I therefore examine the extent to which our conclusions as regards contractors-only ordinances would also apply to area-wide ordinances. In fact, I argue that there are distinct adjustment issues with area-wide ordinances, specifically around the question of price increases and firm relocations.

In Section 6, I examine the possibilities for labor substitution as a final distinct adjustment issue — that is, the extent to which firms might replace their existing minimum wage employees with workers having better skills and/or credentials. Because the covered firms would tend to pay higher than uncovered firms for comparable job types, openings for the jobs with covered firms would likely attract workers with better credentials. This could occur even if firms did not reduce at all the overall number of workers they employ. To the extent that substitution occurs, it would mean that the low-wage workers employed by firms prior to passage of a living wage ordinance-presumably the intended beneficiaries of the ordinance-would rather, in the end, experience job losses. The discussion in this section attempts to gauge the likely magnitude of this substitution effect. I argue that it is likely to occur, though only to a modest extent.

In the paper's concluding Section 7, I briefly pull together the various findings to provide an overall assessment of the likely benefits and costs of living wage ordinances. Of course, the main issue at this point is not the conclusion itself, but rather how the conclusion was derived. The research approach that I summarize in this paper has been to follow the dictum articulated by Alfred Marshall in the statement that serves as this paper's epigram. That is, my co-authors and I have been careful to recognize the range of possible intended and unintended effects of living wage ordinances. But the task of the researcher is not simply to recognize possibilities, but to examine each case, as Marshall says, "to see whether the weights are important or not." My general conclusion with regard to the ordinances I consider here is that their negative effects, 
while present, have not been large enough so as to outweigh the benefits the low-wage workers and their families would obtain through receiving the wage increases stipulated by the ordinances. But it should also be clear from the approach I take that I could not reach this same conclusion $a$ priori for other living wage ordinances. Following Marshall again, the key issue will always be determining in any given situation the relative weights of the possible intended and unintended effects.

Before proceeding, I should also be clear that this paper does not attempt to be comprehensive in its scope. Among other important questions, it does not examine the actual family conditions for workers who would be eligible for living wage increases, nor does it consider alternative policy measures, such as the Earned Income Tax Credit, for raising living standards of low-wage workers. It also does not discuss possible positive multiplier effects from living wage laws—i.e. the benefits of higher household incomes on consumer spending and business sales, and the reduced burdens on governments for spending on poverty alleviation. In general, positive multiplier effects are present, but are small, primarily because the scope of all living ordinances that have been implemented to date are themselves small. However, I have addressed all of these questions in other work (e.g. Pollin and Luce 2000, Pollin 2002, Pollin, Brenner, and Luce 2002) and will continue to examine them in the future.

\section{What is a Living Wage?}

The living wage initiatives that have become law throughout the country are motivated by an initial common initial premise: that people who work for a living should not have to raise a family in poverty. But the term living wage also suggests a more ambitious standard. In A Living Wage: American Workers and the Making of a Consumer Society (1997), Lawrence Glickman writes that in the historical development of the living wage movement, supporters used the "living wage" concept to define a wage level that offers workers "the ability to support families, to maintain self-respect, and to have both the means and the leisure to participate in the civic life of the nation, (p.66)." 
This Glickman definition of a living wage bears a close correspondence with the ideas of Amartya Sen on defining poverty relative to the achievement of what he calls "capabilities."

These capabilities include such things as the ability to read and write, to lead a long and healthy life, to have freedom of movement, and to participate meaningfully in the civic life of the community. But how does one measure the ability to participate in community life? Sen acknowledges the difficulties with this issue, especially when one considers the question according to the level of general affluence of the community in which a person lives. As Sen writes,

The need to take part in the life of a community may induce demands for modern equipment (televisions, videocassette recorders, automobiles and so on) in a country where such facilities are more or less universal (unlike what would be needed in less affluent countries), and this imposes a strain on the relatively poor person in a rich country even when that person is at a much higher level of income compared with people in less opulent countries. Indeed, the paradoxical phenomenon of hunger in rich countries - even in the United States-has something to do with the competing demands of these expenses (1999, pp 89-90).

\section{Quantifying the concepts}

Regardless of whether we define the term living wage narrowly, as adequate to provide a poverty-line living standard, or more generously, in line with both the historical meaning of the term and Sen's conception of attaining adequate capabilities, we still face problems in translating these concepts into concrete monetary amounts. What are the proper dollar values that we should assign to a "poverty-level" living standard or to a higher, but still relatively modest standard that would enable a person to participate meaningfully in one's community life? A considerable amount of value judgment inevitably goes into establishing such standards. Moreover, the cost of living varies considerably between regions and communities in the U.S. Adjustments should therefore be made in light of such cost differences in determining appropriate living-standard thresholds. The only way a researcher can handle these issues is to be explicit in establishing meaningful benchmarks. In what follows, I describe the procedures my colleagues and I used in establishing an appropriate set of "poverty" and "basic needs" thresholds as they applied to 
workers in the Los Angeles area, through which we could then derive a range of hourly wage rates consonant with the idea of a living wage.

First, in terms of measuring "poverty-line" living standards, the U.S. Census Bureau, of course, has been producing such measures since 1963. But a broad range of researchers argue that the government's methodology—which has not been significantly altered since its introduction in 1963 - is no longer adequate. We therefore attempted to develop some viable guidelines for establishing poverty thresholds for our purposes, drawing both from the Census Bureau estimates and the recent professional literature focused on developing improved methodologies.

In terms of measuring a "basic needs" living standard, the California Budget Project (CBP) in Sacramento has done careful research in estimating this. The CBP divided the State of California into 8 regions, of which Los Angeles is one (that with the largest population). The CBP then attempted to measure a "basic family budget" derived from observed costs of housing, food, health care, child care, transportation, clothing, basic telephone service, and a few other essentials. Unlike the Census Bureau's poverty thresholds, the standard of living that the CBP is attempting to measure is, as they explain, "more than a 'bare bones' existence, yet covers only basic expenses, allowing little room for 'extras' such as college savings or vacations," (CBP 2001, p. 1). The CBP estimate therefore can serve as a good reference point in defining a more generous "basic needs" living wage for workers in the Los Angeles Area. ${ }^{4}$ Measuring Poverty Thresholds

In 1963, the U.S. Census Bureau developed a methodology for establishing detailed poverty thresholds for families of different sizes that remains in force at present. The government's approach began by defining what it termed an "economy food plan"-which is the lowest-cost bundle of food items that could ensure that each family member receives the basic

\footnotetext{
${ }^{4}$ Various researchers have conducted similar studies for different regions throughout the country. One reference which includes a large number of such community-specific basic needs budgets is Boushey, Brocht, Gunderson and Bernstein (2001).
} 
caloric minimum. This figure would obviously need to be adjusted according to size of families. The government's methodology then assumed that poor families spend approximately one-third of their budget on food. This figure was derived from government surveys in 1963 of the spending patterns of low-income households. Thus, to generate the dollar figures for the poverty thresholds for 1963, the government simply multiplied the dollar value of the "economy food plan" by three. The poverty thresholds that were obtained by this method in 1963 are then updated annually, by increasing the dollar values of the threshold in accordance with changes in the Consumer Price Index. Using this methodology, the official poverty threshold in 2001 for a family of two was $\$ 11,569$ and for a family of four with two children was $\$ 17,960$.

In recent years, many researchers have questioned the adequacy of this method for establishing poverty thresholds. The most extensive survey of these issues was that sponsored by the National Research Council (hereafter NRC; Citro and Michael 1995). According to the NRC study, establishing overall poverty thresholds on the basis of food costs alone presents many problems. For one thing, there are large variations in housing and medical care costs by region and population groups. In addition, food costs have fallen relative to those for housing for lowincome households since the time the government surveys of spending patterns were conducted forty years ago. The increasing relative costs of childcare over the past 40 years are also not accurately reflected in the government's methodology. This has become increasingly important over time, as labor force participation by mothers has risen.

The NRC study reports on six alternative methodologies to the current official method for measuring absolute poverty for a two adult/two child family. ${ }^{5}$ The thresholds generated by these

\footnotetext{
${ }^{5}$ The NRC study includes consideration of "relative" as well as "absolute" measures of poverty. Relative poverty, as the term suggests, takes account of problems resulting from pronounced inequality in a society, even if that society's average living standard is relatively high; that is, a specific concern addressed with Sen's concept of "capabilities" poverty. However, we focus here only on absolute poverty measures. For an insightful overview on these themes as well as current poverty trends throughout the world, see Keith Griffin, "Problems of Poverty and Marginalization," (2003).
} 
alternative methodologies ${ }^{6}$ are all higher than the official threshold, ranging between 23.7 and 53.2 percent above the official threshold. The average value of these alternative estimates is 41.7 percent higher than the official threshold. This standard for an alternative absolute poverty threshold will help establish our benchmark for a low-end living wage estimate.

\section{$\underline{\text { Regional Living Costs }}$}

The alternative poverty thresholds reported by the NRC do not take account of regional differences in the cost of living. Considerable evidence suggests that living costs for low-wage workers in the LA area are significantly higher than those in other parts of the country. I consider two basic sources here, that of the American Chamber of Commerce Research Association (ACCRA) Cost of Living Index and the 2001 California Budget Project (CBP) figures.

\section{$\underline{\text { Cost of Living Estimates }}$}

The ACCRA data set provides the most detailed statistics on costs of living in approximately 300 cities within the United States. ${ }^{7}$ According to ACCRA, overall living costs in Los Angeles were 26.4 percent above the national average for 1999. Over the 1990s as a whole, this LA living cost differential averages 23.3 percent above the national average for the decade as a whole. From this, it seems reasonable to conclude that for low-wage workers as well as midmanagers in Los Angeles, living costs are approximately 25 percent above the national average.

\section{$\underline{\text { LA Living Costs and Poverty Thresholds }}$}

\footnotetext{
6

${ }^{7}$ At the same time, the ACCRA index has limitations for our purposes. The problem is that the ACCRA index is explicitly designed to measure relative living costs in different regions at what ACCRA describes as a "midmanagement standard of living." Our aim is to understand living costs for low-wage workers, which, obviously, will be in a different category than that for midmanagers. Thus, to make use of the ACCRA data, we first have to consider the extent to which differences in living costs at this "midmanagement" level reflect similar relative cost differences at a living standard appropriate to lowwage workers. In Pollin and Brenner (2000) we provide evidence that the ACCRA index is a reasonable standard for measuring relative costs-of-living for low-wage workers as well as midmanagers in various U.S. cities.
} 
We are now in a position to establish a workable "poverty line" living wage standard for Los Angeles area workers. It follows from the two basic points that emerge from the material we have reviewed: 1) according to the average of the alternative measures of poverty reviewed by the National Research Council, the national poverty line for a family of four is about 40 percent above the official Census Bureau poverty line; and 2) the cost of living in the Los Angeles area is about 25 percent above the national average.

These two figures suggest that an appropriate poverty-line estimate for the Los Angeles area should be about 65 percent above the official Census Bureau poverty line. To present this result cautiously, let us round down, assuming that an appropriate poverty threshold for Los Angeles would be about 60 percent above the official poverty line. Thus, in establishing living wage figures and poverty estimates below, we utilize a "160 percent of official poverty" threshold as our basic measure. We will also report a " 185 percent of official poverty" threshold to measure a "near poor" living standard. Along with these, we will also include the official poverty threshold figures, but will consider these as properly measuring a "severe poverty" standard.

\section{Basic Needs Budget}

As mentioned above, the California Budget Project attempts to measure a standard of living that is more than a "'bare bones' existence, yet covers only basic expenses, allowing little room for 'extras' such as college savings or vacations." The CBP estimates typical costs of housing and utilities, child care, transportation, food, health coverage, payroll and income taxes, and miscellaneous expenses such as clothing, personal care and basic telephone service. The study assumes that the typical family rents housing rather than owns a home, and that the rent they pay is at the lower 40th percentile of "fair market value" rents in the area-i.e. that 40 percent of the rental housing in an area is lower than the fair market value and 60 percent is higher. The family does own a car, but drives an average of only 25 miles per day for commuting. No allowance is made for vacation travel or long commutes. The food budget is based on the Department of Agriculture's "low-cost food plan" which is approximately 25 
percent above its "economy food plan" used in measuring the official poverty threshold. The CBP assumes that a family includes two children, one below and the other above six years old. The study then estimates basic income budgets for three different family types: a single parent family; two parents, with one wage-earner and the other handling child-care; and both parents earning wages. For example, for a single parent family with two children, the study finds the yearly budget would include (in 2001 dollars) $\$ 9,384$ for housing and utilities, $\$ 10,692$ for childcare, $\$ 3,288$ for transportation, $\$ 5,340$ for food, $\$ 4,380$ for health care, $\$ 4,092$ for miscellaneous items, and $\$ 5,662$ for taxes, for a total of $\$ 42,840$.

Overall, the budget estimates generated by this approach correspond well to what we would consider a "basic needs" living standard, or something akin to a minimum amount needed to become capable, in the sense of Sen, of participating meaningfully in community life.

\section{$\underline{\text { Alternative Estimates of Living Wage Standards }}$}

In Table 1, I present alternative estimates for both "poverty-line" and "basic needs" income levels for workers in the Los Angeles area. As we see, the figures are presented for both a three-person/two-child family and a four-person/two-child family. With the fourperson/two-child family, the basic needs figures, derived from the CBP study, are presented in two ways, assuming both one and two wage-earnings in the family. The increased income needs for the two wage-earner family reflects the higher costs of childcare when both adult family-members are working full-time outside the home.

\section{[TABLE 1 BELONGS HERE]}

As we see from the table, the alternative "living wage" rates range fairly widely, according to what one defines as a living wage. Given our discussion above on the inadequacies of the official poverty thresholds, especially as a standard relevant for the Los Angeles area, it is reasonable to exclude these official threshold levels—-what we are terming the "severe poverty" income thresholds—as a level that we could define as corresponding with a living wage. This still leaves wage rates between $\$ 10.98$ and $\$ 20.60$ as the range of values 
associated with different living wage standards for a three-person family with one working adult. For a four-person family, the corresponding wage rate would be between $\$ 13.82$ $\$ 16.93$ with one wage earner in the family. If both adults in a four-person family were working, the average wage for both would need to be $\$ 12.37$ for the family to reach the basic needs threshold.

It is clear from these figures that no single dollar amount can be associated with a living wage threshold. Nevertheless, the figures in the table provide a sense of what an appropriate wage level would be, assuming that workers hold full-time jobs and that they are supporting between one and two additional family members on their wages.

In fact, it may be unrealistic to assume that low-wage workers hold full-time jobs over the course of a year. If they do not, their wage rate would clearly have to be higher to earn an income level corresponding with either a poverty-line or basic needs living standard. At the same time, it may not be the case that workers are trying to support additional family members on their wages, in which case a lower dollar amount would be adequate to supply a living wage.

Such additional considerations need to be weighed carefully in constructing an adequate threshold for a living wage (we have attempted to do so in Pollin and Brenner 2000). But this exercise itself strongly suggests that the California minimum wage, which was at $\$ 5.75$ when we did our research and is now at $\$ 6.75$, are both far below even the low-end estimate of a living wage for a worker living in the Los Angeles area. Indeed, even the current value for the Los Angeles living wage of $\$ 8.27$ plus $\$ 1.25$ for health benefits is still below the low-end range for what would constitute a reasonable living wage figure for Los Angeles.

\section{Estimating Costs of Living Wage Ordinances}

Regardless of what would constitute a "living wage" according to the standards reviewed above or some alternative set of standards, the fundamental question one must still ask regarding any living wage measure is whether its dominant effects will be negative unintended 
consequences, including job losses, firm relocation, and excessive strains on municipal budgets. Most of the research on living wage proposals, including that conducted by my colleagues and me, has therefore focused on estimating the costs of such measures and evaluating how these costs will be absorbed by those who pay them.

The key consideration here is clearly how private firms covered by a living wage ordinance would adjust to their higher labor costs. My colleagues and I have undertaken such cost estimates with respect to the living wage proposals in Los Angeles (Pollin and Luce 2000), New Orleans (Pollin, Brenner and Luce 2002), and Santa Monica, CA (Pollin and Brenner 2000). We utilized varying methodologies and statistical sources depending on the resources available to us in each case. In Table 2, I summarize the findings from these various exercises.

Data sources. As we see first, the studies vary in terms of their statistical sources. In the intitial study for Los Angeles, we relied almost entirely on government statistical sources. With the New Orleans project, we did a large-scale survey of private firms within the city which was our primary data source. We then supplemented the data from the firm survey with government statistical data on employment levels and wage rates. For the Santa Monica study, we surveyed both firms and workers, and these surveys were the major data source for our cost estimates. But as with New Orleans, we also drew upon government statistics, primarily in determining employment levels and wage rates.

Wage and benefit increases. The proposals that we evaluated varied substantially in terms of their basic features. The ordinance for Los Angeles was the most comparable to the measures that have passed in other cities throughout the country. This measure applied only to business firms holding contracts with municipal governments. It stipulated a living wage minimum that was 71 percent above the operative minimum wage at the time, which, for Los Angeles, was the national minimum wage. The Los Angeles ordinance also included provisions for both health care and paid days off for those workers who were not receiving these benefits. 
The New Orleans proposal was far less ambitious in terms of the proposed wage increase, stipulating a 19 percent increase over the national minimum. The New Orleans proposal did not include any provisions for benefits. Finally, the measure in Santa Monica, CA proposed an 87 percent increase over the then California minimum wage of $\$ 5.75$. It also included provisions for health coverage and paid days off similar to those in the Los Angeles measure.

Cost Estimates. There are two components to total costs. The first is the mandated costs for firms of raising their employees to the new living wage minimum as well as the new benefit levels. This includes the pay raises as well as associated increases in payroll taxes. The second component is so-called "ripple effects," which refer to the non-mandated increases in wages and benefits above the living wage minimum that businesses provide to some of their workers after a living wage ordinance is implemented. Businesses provide these non-mandated raises to maintain some semblance of the wage hierarchy that prevailed prior to implementation of a new mandated minimum wage. But estimating ripple effects is necessarily more speculative than estimates for mandated raises, for precisely the reason that ripple effect raises are non-mandated.

As we see in Table 2, our estimates for total costs included a range of between $74-89$ percent for mandated costs, and, correspondingly, $11-26$ percent for ripple effects. In part, this difference in the relative magnitude of the ripple effect reflects variations in our approach to estimating ripple effects which we developed as our work has proceeded. But it also is a function of the differences in the ordinances themselves. Thus, with the Santa Monica ordinance, because the mandated increases rose higher in the overall pay structure, we found that there would be fewer workers within the general wage range who would be likely candidates for non-mandated increases.

Total Costs Relative To Firms Overall Operations. The key findings of our studies is presented in the bottom row of Table 2, which reports estimates of total expected costs of the three ordinances relative to some measure of firms' overall operations. These measures of overall operations were total production costs in Los Angeles, total operating costs (production costs 
minus capital costs) in New Orleans, and total sales in Santa Monica. ${ }^{8}$ As we can see, despite the differences in the ordinances and the methodologies used for estimating costs, there are broad commonalities in our figures for living wage costs relative to the measures we used of firms' total operations. In our Los Angeles study, the average living wage cost estimate was 1.5 percent of total production costs. In New Orleans, the figure was 0.9 percent of operating costs. If the denominator in the New Orleans case would have been total production costs as opposed to operating costs, the living wage cost estimate would have likely been closer to 0.7 percent.

Finally, we have the case of the Santa Monica ordinance. Here, I report three separate figures on total costs, because the cost impacts bifurcated dramatically among the total pool of covered firms. As we see there, our average cost figure was 3.9 percent for all firms. But this included a roughly 10 percent cost ratio for covered hotels and restaurants and a 2.2 percent ratio for all other covered firms.

Two basic features therefore emerge from these studies. First, regardless of the statistical sources and methodology we employed, as well as the specific scalar we used to measure overall operations of covered firms, the average cost to most firms of living wage ordinances are low, somewhere in the range of between $1-2$ percent of firm's total operations. The figure falls even lower when, as with the New Orleans ordinance, the mandates of the ordinance are themselves more modest.

But as the figures from the Santa Monica measure also make clear, there will be firms for which the living wage cost increases will be substantially higher. In Santa Monica, there was a particularly high concentration of hotels and restaurants facing higher costs. This occurred, first, because the mandates of the ordinance in terms of both wages and benefits were high. But more importantly, these high overall cost estimates resulted because the Santa Monica ordinance was designed to target large firms operating in the city's tourist zone. This meant that a

\footnotetext{
${ }^{8}$ More precisely, the measure for Santa Monica was gross revenues, which is therefore inclusive of entities that don't make sales per se.
} 
disproportionate number of covered firms were large hotels and restaurants, and these are the types of firms that employ a high proportion of low-wage workers.

\section{Alternative Adjustments for Covered Firms}

These cost estimates provide the basis for our analysis of the most likely adjustments covered firms will make in response to living wage ordinances. We can usefully divide the covered firms into two groups. What I term "low-impact" firms are the majority of firms in all of our studies, for which the cost increases they face in implementing living wage mandates is in the range of 1-2 percent or less of their total operations. "High-impact" firms are those for which the cost increases are enough above the 1-2 percent range that we might expect them to respond in significantly different ways to living wage-induced cost increases than the majority of firms. Certainly, the hotels and restaurants in Santa Monica, which face cost increases on the order of 10 percent of total sales, would be high-impact firms. In our New Orleans study, we assumed that firms facing cost increases above five percent should be considered as constituting the highimpact category.

In addition to considering the different firm types, we also of course need to examine the specific features of a living wage ordinance in order to evaluate the adjustment paths that firms are likely to pursue. As of this writing, all living wage laws in place are ones that apply only to firms either holding service contracts with, or receiving subsidies from, city governments. We therefore first focus on the adjustment issues as they apply under these "contractors only" type ordinances. At the same time, "area-wide" ordinances, which apply to all businesses of a given size within a defined geographic region, have also been considered, most seriously in Santa Monica and New Orleans, but also in, among other places, Denver and Houston. It is therefore important to consider the distinct features of the adjustment process that would apply in Santa Monica-type "area-wide" measures as well. ${ }^{9}$

\footnotetext{
${ }^{9}$ As of writing in June 2003, the City of Santa Fe, New Mexico is about to implement the nation's first area-wide living wage ordinance. The measure was passed by the Santa Fe City Council in February 2003.
} 


\section{Contractors-Only Ordinances}

\section{Conditions for Low-Impact Firms}

Of course, businesses bidding on city contracts or to receiving city subsidies would want to pass through their increased living-wage induced costs to city governments in the form of more expensive contracts to perform comparable services. However, because the cost increases are small for these firms, it does not follow that cities would have to absorb all these additional costs in order to attract firms to bid on city contracts. Competitive factors, as well as the possibilities for productivity increases and redistribution become important here, again, precisely because the magnitude of the cost increase that needs to be absorbed is small.

Competition. I assume that firms are bidding on municipal contracts in a competitive environment. This means that contract holders cannot be assured of getting their contracts renewed, because at least one serious competitor will also bid on a given contract. ${ }^{10}$ Within such an environment, an increase in costs on the order of $1-2$ percent need not push up contract terms. This is because most firms contracting with cities are eager to maintain these associations and would be unlikely to risk relinquishing them to competitors on the basis of negligible cost increases.

Productivity and Redistribution. On average, firms' productivity will be growing as the living wage is implemented. Even if firms' productivity rises annually by only 1 percent-i.e. at a rate that is half the average rate of productivity growth for all U.S. firms over the last full business cycle of $1991-2000$ - that alone would mean that productivity growth would itself cover two-thirds of a 1.5 percent cost increase. But it is also reasonable to expect that firms' productivity growth should rise at least at a modestly more rapid pace due to the living wage ordinance. This would be due to "efficiency wage" effects-i.e. a decline in turnover and absenteeism because higher wages have made the low-wage jobs more desirable. The costs to

\footnotetext{
${ }^{10}$ Studies of municipal contract bidding, such as Rehfuss (1989) makes clear that this is the most appropriate assumption from which to begin, even after allowing for extensive lobbying, political jockeying and corruption in bidding for municipal contracts.
} 
firms of recruiting and supervising workers should then also decline. Note that allowing for modest productivity gains through efficiency wage effects does not imply that productivity growth would itself fully cover the increased costs of the ordinance. If businesses could increase productivity dollar for dollar through raising wages, an incentive would clearly exist for them to raise wages independent of any living wage mandate. But this incentive to raise wages will diminish when productivity increases only partially offset the cost increases from paying living wages. $^{11}$

Of course, allowing that a firms' productivity increases be used to absorb higher living wage costs does also entail a redistribution of income within such firms, since it would mean that roughly one year's worth of productivity gains would be channeled toward the firms' low wage workers, as opposed to its owners or other employees. But after the one-year adjustment, the distribution of wages and profits within the covered firms could remain constant, while low-wage workers would have received their living-wage increases. All of these adjustments could occur even while the income that firms receive from city contracts would not rise at all.

Obtaining reliable figures on how large these efficiency wage effects are likely to be is very difficult, and estimates therefore range widely. Pollin and Brenner (2002) reviewed much of this evidence as it was relevant for the case of Santa Monica. We attempted to account roughly for the cost savings resulting from all factors-including reduced turnover, absenteeism, supervisory costs as well as increased worker effort—and concluded that "it seems reasonable to suggest that the productivity benefits of the higher living wage for some firms could be as high as $20-25$ percent of their total living wage costs (p. 87)." This estimate would necessarily vary according to size of the mandated wage increase, since efficiency wage effects are a function of workers receiving wage gains large enough to induce changes in their level of job commitment.

\footnotetext{
${ }^{11}$ The literature on efficiency wage effects is voluminous. Pollin and Brenner (2000, p. 93) provides a brief set of major references.
} 
Relocations and layoffs. There is no reason to expect significant layoffs or relocations to occur in considering low-impact firms under contractors' only ordinances. With respect to relocations, there is, in fact, not even a logical basis for anticipating these should occur. This is because a contractors-only living wage ordinance will cover firms that have contracts with a city regardless of whether the firm is located within or outside the city's limits.

Concerning layoffs, there would be no incentive for firms to reduce their scale of operations by shedding labor if the firms are able to absorb their living wage costs through small changes in productivity and distribution within the firm. The key here, again, is that the cost increases of the ordinance would be small; and as such, the benefits of maintaining the desired scale of operations is likely to exceed the costs of moving into compliance with the living wage mandates. Assuming a small employment effect for low-impact firms under living wage ordinances is certainly consistent with the most recent evidence on employment elasticities of minimum wage laws. In summarizing differences that remain among researchers on this question, Freeman writes, "The debate is over whether modest minimum wage increases have "no" employment effect, modest positive effects, or small negative effects. It is not about whether or not there are large negative effects," (1995, p. 833; emphasis in original).

Note also here that the productivity gains derived from efficiency wage effects-i.e. the gains from reduced turnover and absenteeism as well as lower costs of supervising and replacing employees - also does not imply layoffs of a firm's staff of production workers as the means to improving productivity. It rather entails generating modest increases in output from a given supply of employees through reducing administrative costs.

Overall then, with respect to low-impact firms, we would not expect there to be significant negative consequences either in the form of layoffs, relocations or significant budgetary burdens for city governments.

\section{Conditions for High-Impact Firms}


In our study of the Los Angeles ordinance, we found that approximately seven percent of covered firms would experience cost increases of more than 10 percent. Clearly, in cases such as these, the covered businesses would need to pass through a significant proportion of their increased costs if cities were to continue providing the services they are purchasing from these high-impact firms. Nevertheless, even here, significant parts of the increased costs could be absorbed through means other than pass-throughs to city governments. The most important factor here is that, at least in the case of Los Angeles and probably in other cities as well, a large proportion of the high-impact firms are concessionaries. These firms operate on city property, such as airports, zoos, or sports arenas, selling goods and services to the public. These firms thus have the option of attempting to pass through their increased costs in the form of product market price increases. Whether they can succeed in doing so will of course depend on the demand elasticities for the products they sell, a topic we will consider in more depth as it relates to the area-wide ordinances. For now though, the main point to emphasize is that, by definition, concessionaires leasing city property operate within a very confined market area, such as an airport or zoo. This means that their competitors are also operating within the same highly localized market. The competitors would also be covered by the living wage ordinance and would correspondingly face comparable cost increases. Firms in this situation should face relatively weak price elasticities for their products within a range of price increases of less than 10 percent implied by the corresponding living wage cost increases.

There will still be some share of covered firms-perhaps around five percent of total firms in the Los Angeles case-for which the city will need to anticipate large pass-throughs. In the Los Angeles case, if we reasonably allow that this five percent of firms accounted for about 10 percent of total living wage cost increases, that implied for 1996, the year on which our data for this study was based, an outside estimate of pass-throughs on the order of $\$ 7$ million. This obviously is a significant figure in absolute dollars, but it is still an amount that was about 0.2 percent of the city's total budget for that year. 
Considering all of these factors, the major expectation is that with contractors' only type ordinances, the typical situation will be one in which no single entity facing cost increases-i.e. neither the low- or high-impact covered firms, the city governments, nor consumers making purchases at city-leased concessions-would necessarily bear an onerous cost burden, that is, a cost burden that will induce significant negative unintended consequences in the form of layoffs, relocations, or heavy new cost increases for city budgets.

\section{$\underline{\text { Retrospective Studies on Contractors' Only Ordinances }}$}

We now examine the major findings from retrospective studies as to whether this body of evidence is consistent with the conclusions of prospective studies. To date, there have been only three studies that have examined how the implementation of living wage ordinances has affected bidding patterns for city-service contracts and the awarding of contracts with city governments. ${ }^{12}$ The first study, by Weisbrot and Sforza-Roderick (1996), examined contracts immediately after Baltimore implemented a living wage minimum that was 44 percent above the national minimum. Niedt, Ruiters, Wise, and Schoenberger (1999) then conducted a follow-up analysis of of the Baltimore experience three years later. More recently, Brenner and Luce (2003) have examined changes in contract patterns associated with ordinances in Boston, as well as Hartford and New Haven Connecticut.

The initial Weisbrot/Sforza-Roderick study examined 46 contracts in Baltimore whose value of $\$ 19.3$ million represented 72 percent of the total value of contracts that were covered under the ordinance. The key finding of their analysis was that the total value of winning bids after implementation of the living wage ordinance rose by a neglible 0.2 percent in nominal terms relative to the value of the comparable pre-living wage contracts. In real terms, this amounted to a decline of 2.4 percent in the total value of contracts after implementation of the living wage

\footnotetext{
${ }^{12}$ In addition to these retrospective studies of contracting patterns, Neumark (2002) has produced a retrospective analysis of the effects of living wage laws throughout the U.S. on wages, employment, and poverty. However, the Neumark study is neither methologically sound nor robust either statistically or substantively. Brenner, Wicks-Lim, and Pollin (2002) document in detail the weaknesses with Neumark's study.
} 
ordinance. These results by Weisbrot/Sforza-Roderick were then broadly confirmed in the later study of Baltimore by Niedt et al. They examined a total of 26 contracts that could be directly compared before and after the living wage law went into effect. They found that the aggregate cost increase of the winning contract bids was 1.2 percent, again an increase that was below the rate of inflation for any given year between 1995 - 1999 .

The findings by Brenner and Luce are similar, in that they find that costs for a given supply of contracted services did not consistently increase — and indeed more frequently declined - subsequent to implementation of living wage ordinances in Boston, New Haven and Hartford. In considering the Brenner and Luce study, we focus primarily on the results regarding Boston, since the Boston ordinance is far more extensive than those in Hartford or New Haven. The Boston ordinance has covered 166 contracts since its inception in 1999. The New Haven ordinance has covered nine contracts since 1997, while that in Hartford has covered only two contracts since 2000 .

Among the 166 covered contracts in Boston, Brenner and Luce restricted their analysis to those that were likely to employ a sufficient number of low-wage employees such that these firms might experience a significant cost increase from the ordinance. The criterion Brenner and Luce used for including a firm in their sample was whether they employed five or more workers earning between $\$ 8.71$ and $\$ 12.00$ in 2000 , with $\$ 8.71$ being the Boston living wage minimum in 2000. This reduced their sample of covered contracts to 29 firms that could potentially experience a relatively "high impact" from the living wage ordinance. Of these, 23 were contracts for the supplying of various types of special education services.

The results of the Brenner/Luce contract analysis for all three cities are presented in Table 3. First, with Boston, as we see, the weighted average annual change in amount of awarded contracts fell by 9.2 percent. This is over the fiscal years 1999- 00 to 2001-02, during which period the living wage mandate ranged between 57 and 35 percent above the statewide minimum wage (Massachusetts increased its minimum wage from $\$ 5.25$ in 1999 to $\$ 6.75$ in 2002). And 
again, these results include only contracts awarded to firms that might possibly face significant cost increases from the Boston ordinance. The results from the nine contracts analyzed for New Haven are similar. As we see, the weighted average annual change in the awarded contract value was a decline of 10.9 percent.

This pattern of declining contract values is broken in the case of the two contracts awarded in Hartford after implementation of their living wage ordinance in $2000-01$. These two contracts were for security guard services and temporary office assistants. As we see, the weighted value of these contracts did rise substantially, by 33.4 percent. Clearly, with these two cases, the contracting firms were able to receive substantial pass-throughs to cover their increased labor costs.

Of course, there is no reason to expect that living wage ordinances would cause the value of covered contract awards to decline, as they have, on average, in both Boston and New Haven. The implication of these declines in contract values is rather that, for the most part, factors other than living wage mandates have been more significant to firms in choosing how to make what turned out to be winning bids for city contracts.

But as we also saw with the two contracts in Hartford, there will be cases where the implementation of living wage ordinances is associated with substantial increases in contract values. We anticipated such results in our prospective analyses, in considering the situation for the few high-impact firms. Firms such as those in Hartford providing security guards and tempororary office assistance are likely to be among the high-impact firms, in that they both employ a high number of low-wage workers and those workers constitute a high proportion of such firms' total labor costs. But even with such high-impact cases, we cannot assume that the living wage ordinance alone caused the awarded contract values to rise by 33 percent, since no such causal relationship emerged with the 29 high-impact firms in Boston.

In fact, Brenner and Luce observed that the particulars within any given bidding situation are important to determining the final selection of a winning bidder. In the Hartford experience 
with the security guards' contract, the establishment of the living wage mandate persuaded a total of nine firms that they could offer a competitive bid, seven more than had bid the contract before the living wage stipulations were included in the request for proposals. The initial two bidders were those that maintained labor costs as low as possible while the additional seven entrants competed more on the basis of quality than costs alone. This created the conditions in which the firm receiving the contract offered a bid 33 percent above the pre-living wage contract value. But this experience was distinct from that in Boston, in which Brenner and Luce found that contract values generally fell after implementation of living wage mandates in cases where the number of bids on a contract increased.

\section{Adjustments Under Area-Wide Ordinances}

As we have seen, the magnitude of cost increases for firms of living wage ordinances are comparable regardless of whether one is considering a contractors-only or an area-wide

ordinance. But the structure of an ordinance will affect the options available to firms in adjusting to their increased living wage costs. Of course, under area-wide ordinances, firms could adjust to their increased living wage costs through raising productivity or redistributing the firm's overall income just as they could under a contractors-only ordinance. Moreover, the cost pressures under which firms might decide to lay off workers would also be comparable under both an areawide as opposed to a contractors-only ordinance. But there are two adjustment options that would be distinct under an area-wide measure-raising prices or relocation. We consider these in turn.

Price increases. For the case of contractors-only ordinances, we have already discussed the role that price increases can play as an adjustment mechanism in cases where cities have given out concession contracts. With area-wide ordinances, raising prices to reflect increased costs would likely be the least costly and disruptive adjustment path for a high proportion of covered firms. But whether firms can succeed in such a strategy depends on the competitive environment in which they operate and the price elasticity of demand for their products. 
As part of their path-breaking work on minimum wages, Card and Krueger (1995) concluded through observing a variety of situations that price increases were a primary meaus through which firms absorbed their increased costs resulting from higher minimum wages. Indeed, after New Jersey raised its statewide minimum wage in 1993 by 18.8 percent over the national minimum, Card and Krueger found that New Jersey fast-food outlets were able to raise their prices by about the same amount as their total costs were increased, which amounted to about 3.4 percent. But their results are focused on prices at fast-food restaurants. The question we examined in our New Orleans study was how well such results could be generalized to the range of businesses that would be covered by an area-wide municipal living wage ordinance.

Of course, all firms within New Orleans or any other municipality would face the same new living wage requirements. But firms that compete with other firms within the municipality, such as those in the fast-food industry, will likely be better able to raise their prices, since their competitors will have experienced similar mandatory cost increases. Businesses that compete in markets that extend beyond the municipality will correspondingly have more difficulty marking up their prices.

As such, in our New Orleans study, we divided all firms in the city according to whether they compete primarily either with firms outside or inside New Orleans, or whether they face some combination of competitors both inside and outside the city. The first significant result of this exercise concerned firms competing outside the city. Of course, such firms should be least able to pass along their cost increases through raising prices without risking a loss of their customer base to their out-of-town competitors. However, we also found that the firms in New Orleans that fit this category, including manufacturing, mining and legal services firms, would all face only negligible cost increases due to the city's living wage ordinance, since low-wage workers are a correspondingly negligible share of total production inputs for such firms. It is likely that in other cities as well, a comparable set of firms would also be the ones that are both a) 
most exposed to outside competition; but also b) only marginally affected by the mandates of living wage ordinances.

For industries in which firms compete mainly with other firms within the city, it is likely that the situation will approximate that analyzed by Card and Krueger for the fast-food industry in New Jersey. That is, these firms should be able to raise their prices to reflect their higher costs, since all firms in the market would face similar cost increases. The most important industries that are included in this category in New Orleans are restaurants and hotels, which is to say, a large part of what one purchases with a New Orleans hotel room or restaurant meal is its location within the city. This is why hotel room prices are roughly double inside New Orleans proper relative to its immediately surrounding areas.

But how much of the living wage total cost increase can be covered through raising prices will also depend both on price elasticities for individual products as well as the magnitude of the total cost increases. In the case of New Orleans, where the living wage increase was 19 percent above the national minimum, the price increases needed to cover the increased costs would generally be significantly below the 3.4 percent cost increase estimated by Card and Krueger for the New Jersey fast food industry. The average cost increase for New Orleans restaurants was 2.2 percent while that for hotels was 1.7 percent. $^{13}$

Price elasticities for the hotels and restaurants will depend on the market segment one is considering. With relatively high-end hotels and restaurants, both the industry and research literature have long recognized that customers are not strongly price sensitive. For example, a 1997 paper by Lewis and Shoemaker explains how price can serve as a crucial indicator of quality to relatively high-end hotel and restaurant clients. As such, demand in these markets is

\footnotetext{
${ }^{13}$ Though it is notable that for New Orleans fast-food restaurants, we estimated cost increases to be 3.9 percent, that is, very close to the Card/Krueger figure for New Jersey fast-food restaurants. But this result should not be surprising, given that the increase in the minimum wage in the two cases was virtually identical, 18.8 percent in New Jersey compared to the 19 percent increase that would have applied in New Orleans.
} 
likely to be relatively insensitive to price increases on the order of two percent-that is, increases that would fully cover the cost increases associated with the New Orleans living wage ordinance.

Of course, the situation is different when the relevant cost increases are much higher, as with the 10 percent increases estimated for hotels and restaurants in Santa Monica, based on a living wage that would be 85 percent above the statewide minimum. However, even here, one needs to examine the particular market conditions to evaluate the extent to which raising prices may still serve as a viable adjustment mechanism. Thus, in the Santa Monica case, the hotels operate in a market in which the supply of rooms is limited by government growth restrictions. In that situation, high-end hotels were able to raise prices by an average of 14 percent per year (in inflation-adjusted dollars) between 1994 - 99 without experiencing any fall off in occupancy rates. These hotels also recovered quickly from a fall in revenues resulting from the September 11, 2001 terrorist attacks. The hotels' pricing power is a reflection of the rents hotels are able to obtain through operating in a restricted market. ${ }^{14}$ By contrast, restaurants in Santa Monica do not operate in a restricted market and therefore do not possess the same capacity to earn rents from their operations. We had therefore anticipated that they would be far less capable of using price increases as a means of adjusting to their increased living wage costs.

There is, finally, the situation for firms that compete both inside and outside the borders of a municipality. Firms in this situation are likely to be very heterogeneous. In New Orleans, for example, we estimated that this category of firms included advertising and building maintanance firms, wholesale traders, and retail outlets, including food stores. Conditions will vary considerably among these firm types, so one cannot generalize about the role of price increases as one adjustment mechanism Nevertheless, we can say that in some cases, price

\footnotetext{
${ }^{14}$ Stiglitz (1993) explains the concept of economic rent as follows: "The economic concept of rent has its historic origins in the payments made by farmers to landlords for the use of land, but today its application is much broader. The critical characteristic of land in this regard is that it is inelasticallly supplied, so that high payments for land (higher rents) will not elicit a greater supply....Many other factors of production have the same inelastic character," (p. 357-58).
} 
increases will be able to absorb at least some of the cost increases associated with the costs of living wage ordinances.

Overall then, price adjustments — and therefore the passing on of increased living wage costs to product market customers-is likely to be an important adjustment mechanism to areawide living wage ordinances for a substantial proportion of covered firms. But to obtain a clear understanding of how important price adjustments will be in any given situation will require an analysis of the individual cases. In each case, one would need to obtain a sense of the magnitude of cost increases for firms relative to their overall scale of operations; the broad competitive environment for the covered firms; and the elasticity of demand for firms' products.

$\underline{\text { Relocation. }}$ Raising the living wage minimum for all firms within a given municipality does create an incentive for firms to escape coverage by moving to a neighboring municipality. However, the force of this effect will depend, first, on how large the firms' newly mandated costs are relative to other considerations. With low-impact firms, the incentives to relocate will be small under all circumstances.

But even with a large proportion of high-impact firms, the costs of relocation will exceed the expected benefits. Restaurants and hotels are likely tied to their specific locations-one cannot stay, for example, in a New Orleans hotel unless the hotel is actually within New Orleans. In the case of other types of businesses, such as those providing janitorial services, the firm itself need not remain located within the given municipality. But if the employees of the firm were still working within the boundaries of the municipality, they would still fall under the terms of the living wage ordinance. These firms as well would have little incentive to relocate.

The types of firms for which the benefits of relocation would exceed costs would be high-impact firms whose business is not location-specific. In both our Los Angeles and New Orleans studies, we have estimated the proportion of firms that would likely fall into this category. In both cases, it is a small number of the total of covered firms. In New Orleans, for example, where our estimates are more precise because they are based on our own survey of local 
business firms, we estimated that there were 209 firms whose cost increases would exceed five percent of their total operating budgets and whose businesses are not obviously location-specific. These 209 firms constitute 1.6 percent of the total universe of 12,439 New Orleans firms. Whether relocation would be viable for any given firm among this group would depend on the nature of their business. These firms were located fairly evenly across four industrial categories in New Orleans, wholesale trade, business services, retail trade other than restaurants and hotels, and "other services." In some cases, such as with retail trade, firms could risk losing sales through relocation if their customers' purchasing habits are at least partially tied to convenience. In other cases, such as advertising agencies, firms could move without losing customers. There are also cases such as we have discussed above with janitorial firms, in which the firm would still have to pay living wages to workers whose jobs were located within the city, regardless of where the firm's offices were located. In short, it is likely that even among these roughly 200 firms, only a relatively small subset would be in a situation in which the benefits of relocation would outweigh the costs. ${ }^{15}$

Moreover, the relevant issue with this subset of firms would be what the costs would be to the City of New Orleans if these firms did indeed relocate. In our previous work, we worked from the reasonable assumption that the firms would be relocating strictly to avoid paying the higher minimum wage. As such, we would expect the firms to move just outside the city limits, so as to retain, if from a different specific location within the metropolitan area, their same New Orleans-based operations and customer base. One crucial implication of this point is that no net employment losses would occur due to these firms' relocation. Workers would be able to retain

\footnotetext{
${ }^{15}$ On balance, this conclusion is buttressed by research on a related topic-the effects of differential property tax rates on the location decisions of export-oriented firms within the United States. Thus Bartik $(1991,1992)$ has shown that export-oriented firms are likely to be highly sensitive to differences in property tax rates between suburban locations. However, the effects of tax differentials appear to be substantially weaker in comparing central city locations with the suburbs. Bartik argues persuasively that this is likely the case because central cities may not be good substitutes for suburban locations.
} 
their same jobs without moving, which in turn would mean no change in the city's housing market.

The primary loss to the City of New Orleans would therefore be the loss of the its authority to tax these firms. In our earlier work, we made an upper-limit assumption that roughly one-half of the 200 firms would move out of the city. Based on that assumption, and on the stipulations of the City's tax codes, we estimated that the City would lose about $\$ 2$ million in sales and use taxes through the relocation of 100 firms. This is a large absolute amount, of course. But to put it in perspective, it is equal to 0.4 percent of the City’s $\$ 499.1$ approved budget for 1999 .

Finally, from our examinations of Los Angeles and Santa Monica as well as less formal considerations in other cities, I would anticipate a relocation effect of roughly this order of magnitude for other cities as well through implementation of an area-wide living wage ordinance.

\section{Labor Substitution}

Even if firms neither relocated nor reduced their number of employees at all in response to a living wage ordinance, a negative unintended consequence of such measures could still result through labor substitution-i.e. firms replacing their existing minimum wage employees with workers having better skills and/or credentials, which could occur even in the absence of any net job loss. Because the firms covered by a living wage law would pay higher than comparable positions with uncovered firms, openings for the jobs with covered firms would likely attract workers with somewhat better credentials, on average, than those in the existing labor pool.

But how would employers be able to distinguish more qualified workers in this expanded pool of job seekers? This is not an obvious question. For most of the jobs that would be covered by living wage ordinances-e.g. janitors, nurse's aids, garderners, parking lot attendants, elevator operators, hotel maids, restaurant dishwashers, and retail cashiers - the qualities that would distinguish one worker from another will not be based primarily on formal qualifications such as years of schooling. Hiring "better" workers would rather most likely entail hiring people who 
work harder and are more conscientious in their duties. But employers will not be able to observe those on-the-job work habits until an employee is actually on the job. The employers are therefore likely to rely on formal qualifications such as years of schooling or English language skills as proxy measures—however inadequate—of workers' job specific skills. Thus, the primary way in which labor substitution would occur after a living wage ordinance were implemented would be through better credentialed workers seeking jobs covered by a living wage ordinance that would not have applied if the wages for these jobs were still closer to the national minimum wage level.

We addressed this issue in both our New Orleans and Santa Monica studies using the same technique and analytic framework. We first examined differences in personal characteristics for two groups of workers- those who fell within the wage range close to the preliving wage minimum and those who would fall within the living wage minimum. Thus, in the New Orleans case, we examined workers earning between $\$ 5.15$ and $\$ 5.64$ in the first group; and between $\$ 6.15$ and $\$ 6.64$ in the second group. To obtain a sample of low-wage workers large enough to make this exercise reliable, we had to enlarge the pool to include not workers employed in New Orleans itself, but rather a sample encompassing workers in all of Louisiana as well as Alabama, Arkansas, Georgia, and Texas. The results of this exercise are shown in Table 4.

\section{TABLE 4 BELONGS HERE}

As we see from the table, the percentage of those without high school diplomas falls by 15.8 percentage points in moving from the $\$ 5.15$ to the $\$ 6.15$ wage category. Correspondingly, those with high school diplomas, some college, and college degrees each rise by between $4.5-$ 6.5 percentage points. Not surprisingly, the percentage of teenagers falls by 18.8 percentage points in moving from the lower to the higher wage category. The $\$ 6.15$ wage category has fewer females but, surprisingly, more non-native English speakers. The differences in personal characteristics between the low- and high-wage categories are somewhat higher in our Santa 
Monica study simply because the living wage increase is itself larger. Thus, the high-end wage band that we examined with the Santa Monica study was between $\$ 9.10$ and $\$ 10.75$ rather than $\$ 6.15-\$ 6.64$.

Nevertheless, in both cases, it is important to emphasize that such figures are useful only in establishing an upper limit as to the likely degree of labor substitution. This is because, in considering these figures, we are effectively asking whether, if covered firms were newly hiring their entire low-wage work force, and if they were advertising their job openings at a wage rate in the range of $\$ 6.15$ rather than $\$ 5.15$ (to take the New Orleans case), how would the profile change of the newly hired workers?

Having thus defined the upper limit of labor substitution effects through these figures, the next step is to recognize why any actual labor substitution effects are likely to be far more modest. This is first of all because, in reality, businesses are unlikely to newly hire their entire workforce after a living wage law was enacted, nor would they want to do so. Rather, as we have discussed, workers earning the higher minimum will be less inclined to leave their jobs, and their work effort should correspondingly rise. By the same token, businesses are not likely to terminate their existing workers, even if they have relatively poor formal credentials, as long as their performance is satisfactory. ${ }^{16}$ Recognizing these various factors, we would still expect some substitution to occur, both by educational credentials and age, though, the magnitude of such substitutions is likely to be modest.

\section{Conclusions}

The findings I've summarized with respect to labor substitution effects are reflective of my overall evaluation of the evidence concerning negative unintended consequences, including

\footnotetext{
${ }^{16}$ Another reason the Table 6 figures represent an upper limit measure of the substitution effect is that the minimum $\$ 5.15$ category includes a relatively high proportion of teenagers who do not have high school diplomas simply because they are still in high school. If $\$ 6.15$ became the new minimum wage for New Orleans, then the proportion of high school students would rise in this new minimum category, thereby also increasing the total share of those in this category with less than a high school diploma.
} 
layoffs and labor substitution, relocations, and costs to city governments. An analysis of these potential negative consequences is central to any assessment of living wage ordinances. They could certainly be significant and even overriding features of any given ordinance. But when the impact of living wage ordinances on most covered firms is of the order of $1-2$ percent of these firms total production costs or sales, the likely adjustments firms will make will be of a comparably modest magnitude. As such, raising prices and productivity by a small amount, or redistributing the firm's income downward modestly, are likely to be the predominant means through which covered firms will absorb their increased costs. In such cases, the gains of living wage ordinances to low-wage workers and their families will be larger than the per unit costs of the ordinances that would be borne by covered firms, consumers, taxpayers or city governments. To put this another way: a well-designed living wage ordinance has the characteristic that its benefits will be concentrated among low-wage workers and their families while the costs can be broadly diffused among covered firms, consumers, taxpayers and city governments.

Moreover, as we discussed, even in cases where cost increases are large, as with the hotels and restaurants in under the area-wide Santa Monica ordinance, it still doesn't follow that firms will necessarily experience significant difficulties absorbing the cost increases via price, productivity, and redistribution. The Santa Monica hotels earn substantial rents through the restrictions on supply established by the city government's growth restriction policies. In that particular case, the adjustment that the hotels would make through redistribution would simply imply a broader sharing of the policy-induced rents that the firms have heretofore been able to maintain for themselves. Restaurants in Santa Monica, by contrast, do not benefit through growth restriction policies. They would have far greater difficulties absorbing cost increases on the order of 10 percent.

In other cases, as with the security guard contract under the Hartford contractors-only ordinance, we should expect that high impact firms will successfully pass through to city government their increased costs. But our evidence shows that this does not hold as a general 
rule. It clearly did not happen as the general case with the Baltimore, New Haven, and Boston ordinances. As such, cities should certainly be prepared to bear some of new costs of ordinances that would apply to high-impact firms. But even here, these cost increases are likely to be a small fraction of the overall budgets of city governments, as we saw with the Los Angeles case. The only situation in which the cost increases would be large relative to a city's overall budget would be when 1) an ordinance would cover a large number of high-impact firms; and 2) the contracts with these high-impact firms would be a significant share of a city's overall budget.

Of course, these conclusions are based on living wage ordinances in which the mandated raises ranged between 19 and 87 percent above the relevant minimum wage. This is a wide range, but, as we have seen, it still does not encompass the full scope of values that one could plausibly define as a "living wage." As we saw for Los Angeles, a reasonable case can be made for defining a living wage as being somewhere in between $\$ 11$ - \$20 an hour, depending on family sizes and types. On the other hand, a \$20/hour living wage would mean a three-fold increase over the current California minimum of $\$ 6.75$ The cost increases associated with a living wage at this level would obviously create much more susceptibility to all the potential negative consequences of these measures.

Two questions capture this basic tension concerning the evaluation of living wage laws: 1) What constitutes a reasonable standard for living wages in the United States according to the approaches articulated by Sen and others; and 2) What is the tipping point at which a living wage mandate would trigger negative unintended consequences to a significant degree? This paper presents evidence concerning both a reasonable range of living wage values and the effects of various living wage ordinances. But more importantly, I have tried to be clear in presenting a methodology for the detailed analysis of living wage laws according to Alfred Marshall's dictum, that we place "greater proportionate stress" not simply on recognizing potential effects in an 'all else equal' world; but on measuring the relative weights of these potential effects under various circumstances. 


\section{References}

Bartik, Timothy (1991) Who Benefits from State and Local Economic Development Policies? Kalamazoo, MI: W.E. Upjohn Institute for Employment Research.

Bartik, Timothy (1992) "The Effects of State and Local Taxes on Economic Development: A Review of Recent Research," Economic Development Quarterly, 6(1), 102-110.

Boushet, Heather, Chauna Brocht, Bethney Gunderson and Jared Bernstein (2001) Hardship in America: The Real Story of Working Families, Washington, D.C.: Economic Policy Institute.

Brenner, Mark and Stephanie Luce (2003) "Living Wage Implementation and City Contract Costs: Evidence from New England," Political Economy Research Institute, manuscript in process.

Brenner, Mark, Jeanette Wicks-Lim, and Robert Pollin (2002) "Measuring the Impact of Living Wage Laws: A Critical Appraisal of David Neumark's 'How Living Wage Laws Affect Low-Wage Workers and Low-Income Families," Political Economy Research Institute Working Paper \#43, http://www.umass.edu/peri/pdfs/WP43.pdf

California Budget Project. (2001) Making Ends Meet: How Much Does it Cost to Raise a Family in California? Sacramento, CA: California Budget Project. October, http://www.cbp.org/2001/r0109mem.htm

Card, David and Alan B. Krueger. (1995) Myth and Measurement: The New Economics of the Minimum Wage. Princeton University Press.

Citro, Constance F., and Robert T. Michael, eds. (1995) Measuring Poverty: A New Approach. Washington, DC: National Academy Press.

Freeman, Richard (1995) "What Will a 10\%...50\% ...100\% Increase in the Minimum Wage Do?" Industrial and Labor Relations Review. 48(4): 830-834.

Glickman, Lawrence (1997) A Living Wage: American Workers and the Making of Consumer Society. Ithaca, NY: Cornell University Press.

Griffin, Keith (2003) "Problems of Poverty and Marginalization," Indicators: The Journal of Social Health 2(2), 22-48.

Lewis, Robert C. and Stowe Shoemaker (1997) "Price-Sensitivity Measurement; A Tool for the Hospitality Industry", Cornell Hotel and Restaurant Administration Quarterly, April, pp. 44-54.

Niedt, Christopher, Greg Ruiters, Dana Wise, and Erica Schoenberger (1999) "The Effects of the Living Wage in Baltimore,” Working Paper \# 119, Washington, D.C.: Economic Policy Institute.

Neumark, David (2002) "How Living Wage Laws Affect Low Wage Workers and LowIncome Families,” Public Policy Institute of California Report \#156.

Pollin, Robert (2002) "Living Wages, Poverty, and Basic Needs: Evidence from Santa Monica, CA," Political Economy Research Institute Working Paper \#33, http://www.umass.edu/peri/pdfs/WP33.pdf 
Pollin, Robert (2003) Contours of Descent: U.S. Economic Fractures and the Landscape of Global Austerity, London: Verso Press.

Pollin, Robert and Mark Brenner (2000) Economic Analysis of Santa Monica Living Wage Proposal, Political Economy Research Institute Research Report \#2, http://www.umass.edu/peri/pdfs/RR2.pdf

Pollin, Robert, Mark Brenner and Stephanie Luce (2002) "Intended vs. Unintended Consequences: Evaluating the New Orleans Living Wage Proposal", Journal of Economic Issues, December.

Pollin, Robert and Stephanie Luce (2000) The Living Wage: Building a Fair Economy, New York: The New Press, paperback edition.

Rehfuss, John (1989) Contracting Out to Government, San Francisco: Jossey-Bass Publishers.

Sen, Amartya (1999) Development as Freedom, New York: Random House.

Stabile, Don (1993) Activist Unionism: The Institutional Economics of Solomon Barkin, Armonk, NY: M.E. Sharpe.

Stiglitz, Joseph (1993) Economics. New York: W.W. Norton and Company.

Weisbrot, Mark and Michelle Sforza-Roderick (1996) "Baltimore's Living Wage Law," Washington, D.C.: The Preamble Institute. 
Table 1.

Alternative Living Wage Income and Wage Levels for Los Angeles Area

(figures are in 2001 dollars)

\begin{tabular}{|c|c|c|c|c|c|}
\hline & \multicolumn{3}{|c|}{ Poverty-level Income } & \multicolumn{2}{|c|}{ Basic Needs Income } \\
\hline & $\begin{array}{c}\text { Severe } \\
\text { Poverty } \\
\text { (official } \\
\text { poverty line) }\end{array}$ & $\begin{array}{c}\text { Poor } \\
\text { (160\% of } \\
\text { Official } \\
\text { Poverty } \\
\text { Line) }\end{array}$ & $\begin{array}{c}\text { Near-Poor } \\
\text { (185\% of Official } \\
\text { Poverty Line) }\end{array}$ & $\begin{array}{l}\text { One Wage } \\
\text { Earner }\end{array}$ & $\begin{array}{c}\text { Two Wage } \\
\text { Earners }\end{array}$ \\
\hline \multicolumn{6}{|l|}{3 Person/2 Child Family } \\
\hline Annual Income & 14,269 & 22,830 & 26,398 & 42,845 & -- \\
\hline $\begin{array}{r}\text { Hourly Wage-Rate for } \\
\text { Full-Time Job }\end{array}$ & 6.86 & 10.98 & 12.69 & 20.60 & -- \\
\hline \multicolumn{6}{|l|}{4 Person/2 Child Family } \\
\hline Annual Income & 17,960 & 28,736 & 33,226 & 35,207 & 51,459 \\
\hline $\begin{array}{r}\text { Hourly Wage Rate for Full- } \\
\text { Time Job }\end{array}$ & 8.63 & 13.82 & 15.97 & 16.93 & $\begin{array}{r}12.37 \\
\text { for both jobs }\end{array}$ \\
\hline
\end{tabular}

Sources: Current Population Survey (2001); California Budget Project (2001). 
Table 2. Cost Estimates of Alternative Living Wage Ordinances

\begin{tabular}{|c|c|c|c|}
\hline & $\begin{array}{l}\text { Los Angeles } \\
\text { (1998 study) }\end{array}$ & $\begin{array}{c}\text { New Orleans } \\
(1999 \text { study })\end{array}$ & $\begin{array}{c}\text { Santa Monica } \\
(2000 \text { study })\end{array}$ \\
\hline $\begin{array}{l}\text { Statistical sources } \\
\text { for estimates }\end{array}$ & $\begin{array}{l}\text { Primarly government } \\
\text { statistics }\end{array}$ & $\begin{array}{l}\text { Firm survey } \\
\text { supplemented with } \\
\text { government statistics }\end{array}$ & $\begin{array}{l}\text { Firm and worker surveys } \\
\text { supplemented with government } \\
\text { statistics }\end{array}$ \\
\hline $\begin{array}{l}\text { Coverage of } \\
\text { ordinance }\end{array}$ & $\begin{array}{l}\text { Govt. contractors over } \\
\$ 25,000 \text { and subsidy } \\
\text { recipients over } \$ 1 \\
\text { million or } \$ 100,000 \\
\text { annually }\end{array}$ & $\begin{array}{l}\text { All firms in city with } \\
\text { more than } \$ 500,000 \text { in } \\
\text { annual sales }\end{array}$ & $\begin{array}{l}\text { All firms in city's tourist zone } \\
\text { with more than } \$ 3 \text { million in } \\
\text { annual sales }\end{array}$ \\
\hline $\begin{array}{l}\text { Mandated wage } \\
\text { increase above } \\
\text { minimum } \\
\text { (percentages) }\end{array}$ & $71 \%$ & $19 \%$ & $87 \%$ \\
\hline Benefits & $\begin{array}{l}\text { Health-29\% of } \\
\text { minimum wage; } \\
12 \text { paid days off }\end{array}$ & Not included & $\begin{array}{l}\text { Health-22\% of minimum } \\
\text { wage; } \\
15 \text { paid days off }\end{array}$ \\
\hline $\begin{array}{l}\text { Direct costs as } \\
\text { proportion of total } \\
\text { costs }\end{array}$ & $80.4 \%$ & $74.4 \%$ & $89.2 \%$ \\
\hline $\begin{array}{l}\text { Ripple effects as } \\
\text { propotion of total } \\
\text { costs } \\
\end{array}$ & $19.6 \%$ & $25.6 \%$ & $10.8 \%$ \\
\hline $\begin{array}{l}\text { Total costs of } \\
\text { ordinance relative to } \\
\text { firms' overall } \\
\text { operations }\end{array}$ & $\begin{array}{l}1.5 \% \text { of } \\
\text { production costs }\end{array}$ & $\begin{array}{l}0.9 \% \text { of } \\
\text { operating costs }\end{array}$ & $\begin{array}{l}\text { Percentages of total sales: } \\
\text { All firms-3.9\% } \\
\text { Hotels and restaurants-10\% } \\
\text { Other firms-2.2\% }\end{array}$ \\
\hline
\end{tabular}

Sources: Pollin and Luce (2000), Pollin, Brenner and Luce (2002), Pollin and Brenner (2000). 
Table 3. City Service Contract Awards in Boston, New Haven and Hartford, Before and After Living Wage Ordinance

\begin{tabular}{|c|c|c|c|}
\hline & Boston & New Haven & Hartford \\
\hline $\begin{array}{l}\text { Fiscal year of } \\
\text { implementation }\end{array}$ & $1999-2000$ & $1997-98$ & $2000-01$ \\
\hline $\begin{array}{l}\text { Mandated wage } \\
\text { increase above } \\
\text { statewide minimum }\end{array}$ & $\begin{array}{l}+57 \% \text { in } 1999 \\
+35 \% \text { by } 2002\end{array}$ & $\begin{array}{l}+43 \% \text { in } 1997 \\
+46 \% \text { in } 2001\end{array}$ & $\begin{array}{l}+33 \% \\
+86 \% \text { with health } \\
\text { benefits }\end{array}$ \\
\hline $\begin{array}{l}\text { Average annual } \\
\text { change in contract } \\
\text { values } \\
\text { (weighted by } \\
\text { contract size) }\end{array}$ & $\begin{array}{l}-9.2 \% \\
{[29 \text { contracts }]}\end{array}$ & $\begin{array}{l}-10.9 \% \\
{[9 \text { contracts] }}\end{array}$ & $\begin{array}{l}+33.4 \% \\
{[2 \text { contracts] }}\end{array}$ \\
\hline
\end{tabular}

Source: Brenner and Luce (2003). 
Table 4.

\section{Personal Characteristics of Low-Wage Workers \\ in Five Southern States, 1999}

\begin{tabular}{lccc}
\hline & Hourly Wage Categories & $\begin{array}{c}\text { Differences between } \\
\text { two wage categories } \\
\text { (column 2 - 1) }\end{array}$ \\
& $\begin{array}{l}(1) \\
\text { (1999 dollars) }\end{array}$ & $\begin{array}{c}(2) \\
\$ 5.15-5.64\end{array}$ & $30.2 \%$ \\
\hline Less than high school diploma & $46.0 \%$ & $38.0 \%$ & $-15.8 \%$ \\
High school diploma or GED & $31.5 \%$ & $25.2 \%$ & $+6.5 \%$ \\
Some college & $20.7 \%$ & $6.6 \%$ & $+4.5 \%$ \\
Bachelor's degree or more & $1.9 \%$ & $13.4 \%$ & $+4.7 \%$ \\
Under 20 years of age & $32.2 \%$ & 33.9 & $-18.8 \%$ \\
Average age (years) & 30.6 & $61.5 \%$ & +3.3 \\
Female & $65.5 \%$ & $20.8 \%$ & $-4.0 \%$ \\
English as second language & $13.9 \%$ & & $+6.9 \%$ \\
\hline
\end{tabular}

Source: Current Population Survey, Outgoing Rotation Group 1999

Note: In addition to Louisiana, the southern states in the sample are Alabama, Arkansas, Georgia, and Texas. 